\title{
Rethinking Work and Family Policy: The Making and Taking of Parental Leave in Australia
}

\author{
Marian Baird, Ph.D., University of Sydney, NSW, Australia ${ }^{1}$ \\ Adam Seth Litwin, MIT Sloan School of Management ${ }^{2}$
}

\#WPC0020

\begin{abstract}
${ }^{1}$ Discipline of Work and Organisational Studies, School of Business, Faculty of Economics and Business, University of Sydney, NSW, Australia ${ }^{2}$ Institute for Work and Employment Research, Sloan School of Management, Massachusetts Institute of Technology, Cambridge, MA, USA

Correspondence to: Dr. Marian Baird, Work and Organizational Studies, School of Business H69, University of Sydney, NSW 2006, Australia. Tel: +61 29351 6439; Emailm.baird@econ.usyd.edu.au
\end{abstract}

\section{Submitted to International Review of Psychiatry}

For information regarding the MIT Workplace Center or for additional copies of this working paper (\#WPC 0020), please email workplacecenter@mit.edu, call (617)253-7996 or visit our website: web.mit.edu/workplacecenter

Marian Baird and Adam Seth Litwin. All rights reserved. This paper is for the reader's personal use only. This paper may not be quoted, reproduced, distributed, transmitted or retransmitted, performed, displayed, downloaded, or adapted in any medium for any purpose, including without limitation, teaching purposes, without the authors' express written permission. Permission requests should be directed to m.baird@econ.usyd.edu.au 


\section{Rethinking Work and Family Policy: The Making and Taking of Parental Leave in Australia}

\section{Summary}

Despite the continued increase in female participation rates, Australia remains one of only two developed nations in the world without a paid maternity leave scheme. While research interest and public policy debate about paid maternity leave entitlements continues, little is known about the actual utilization of the 52 weeks unpaid parental leave that is currently available to all employees. Moreover, research and policy debate on the availability and provision of paid paternity leave has only just begun. This paper argues that, given the gendered nature of employee entitlements, it is time to reevaluate all aspects of parental leave policy in Australia. Using unique data from a national survey of Australian employees, the paper provides a statistical analysis of the use of unpaid parental leave and the availability of paid maternity leave. The paper models the availability of paid maternity leave to Australian employees as a function of demographic and organizational characteristics, including annual income, union status, and establishment size. A parallel analysis of the likelihood that an individual has used the unpaid parental leave provision is also provided. The results show that the existing unpaid parental leave provision is rarely used and that the current availability of paid maternity leave is inequitable. The paper discusses the conceptual and policy implications of these results and concludes that a re-thinking of parental leave policy in Australia is essential if gender inequities at work and in society are to be addressed.

\section{Introduction}

In an era in which many employees in market economies are time-poor and organisations seek increasing competitiveness and efficiency, one of the most pressing concerns of workers, employers, and governments is how best to balance work and family needs. The rising tensions, particularly for women, between the demands of work and the demands of home and one's personal life, have stimulated debate about organisational and public policies designed to address these problems. These "familyfriendly" policies (which may include maternity, paternity, parental, and carers' leave, flexible working hours, and child and elder care) now vary markedly between organisations and countries. For instance, in relation to leave, while there is some similarity between the US and Australia as both enacted universal arrangements for unpaid parental leave in the early 1990s, the UK and New Zealand governments by contrast, provide relatively generous paid maternity and paternity leave schemes for employees. As a result, Australia and the US remain the only two OECD countries without a legislative mandate providing paid maternity leave protection to working women (Heymann, Earle, Simmons, Breslow, \& Kuehnhoff, 2004).

Whereas elected regimes in both these nations favour laissez faire solutions over active employment policy, the issue of paid maternity leave for Australian female workers has garnered markedly more media visibility, and thus, the attention of legislators. 
Recently, Australia's Human Rights and Equal Opportunity Commission (HREOC) released a recommendation for an across-the-board paid maternity leave scheme (Sex Discrimination Unit, 2002b). Critics claimed the proposal amounted to "middle-class welfare" (Kearney, 2002) and argued that discretion for offering and funding such policies should be left to workers and their employers.

This paper aims to fill a dual void. The dearth of comprehensive statistics documenting the use of the existing unpaid parental leave provision by Australian workers has itself created a critical gap for policymakers. This vacuum must be filled before lawmakers can credibly problematize the labour market's ability to sort out the matter of paid leave on its own (Sex Discrimination Unit, 1999, 2002b). Using fresh data from a crosssectional survey of Australian employees, the paper addresses some of the deficiencies in knowledge about the use of unpaid parental leave and access to paid maternity. These findings and the policy prescriptions derived from them will have material consequences for women as well as men wanting to find success and comfort in both their work and personal lives, with potentially positive spillovers for employers, co-workers, family members, and wider society. Our main result is that the existing, unpaid scheme is rarely used, and that private sector employers outside the unionized sector have not been competitively-driven to provide a paid maternity leave benefit. Thus, women do not have access to paid maternity leave, and the objectives of the existing policy on unpaid leave remain unmet.

\section{Background}

In Australia, "parental leave" refers to the period of 52 weeks leave available to mothers and fathers upon the birth or adoption of a child, intended to facilitate the reconciliation of employment and personal responsibilities. First granted to women in 1979 and then extended to fathers in 1991 by the Australian Industrial Relations Commission (AIRC), the entitlement covered only a portion of the labour force. In 1993, the Industrial Relations Reform Act (Commonwealth) extended the entitlement to the rest of the nation's workforce. This policy, restated in the 1996 Workplace Relations Act (Commonwealth), remains in effect today. Unpaid parental leave is now available to all employees after 12 months continuous service, with a guaranteed right of return to the employee's former job. An important aspect of the legislation is in terms of its job protection function, in theory enabling those people exercising their unpaid leave to maintain their connection with paid employment.

In contrast to the relatively generous provision of unpaid parental leave, there is no legislative provision for paid maternity leave in Australia, except for federal and state public servants. Federal public servants have had access to 12 weeks paid maternity leave since 1973, but the provision varies widely for state public servants. Only three states offer their government employees the 14 weeks paid maternity leave called for by the International Labour Organization (ILO), with the largest, New South Wales just having met the standard in early 2005 (Baird, Brennan, \& Cutcher, 2002). One state, South Australia, continues to provide its public servants with just two weeks of paid maternity leave. This lack of universal coverage generated considerable controversy 
and debate in Australia, culminating in HREOC's ${ }^{1}$ independently reviewing costs and benefits of a menu of strategies for providing paid maternity leave. In December 2002, HREOC recommended a scheme to provide all working women 14 weeks of leave. The report proposed benefits be valued at the federal minimum wage (approximately AU\$430 per week) and funded from general revenue (Sex Discrimination Unit, 2002a).

Proponents built their case on medical, psychological, and economic grounds. The policy recognizes the social shifts which have occurred in relation to women's increasing participation in higher education and paid employment as well as their increasing contribution to family incomes. Along similar lines, HREOC's vision ensures women do not bear the full cost of labour market intermittency, either in terms of depreciated human capital or foregone contributions to retirement savings vehicles. Those opposed to the HREOC plan argue that the policy favours working women over those women opting to stay at home, asserting both a philosophy of individual choice and the existing provision for guaranteed right of return to one's job (Australian Department of Employment and Workplace Relations, 2001). Rather than enacting and funding labour market regulation, HREOC's detractors prefer that entitlements be negotiated at the enterprise-level via collective bargaining or that they materialize as an element of competitive human resource (HR) strategy.

With the exception of Glezer's (1988) investigation prior to the universal provision of unpaid parental leave, there has been negligible research on the use of unpaid parental leave in Australia. Between the elected government's disinclination for labour market regulation and a lack of fresh data for policymakers to mull over, it comes as no surprise that HREOC's proposal for paid maternity leave remains unimplemented. Clearly, policy issues of access, coverage, and equity remain unresolved, as do questions about its impact on work and career choices.

\section{Theory and Hypotheses}

Since unpaid leave has been available for a decade, enough time has passed to assess whether workers have actually used the policy. The prospective state of a paid leave entitlement calls for theorizing not about past use, but instead about which members of the labour force presently have access to such policies in their workplaces.

Without a universal entitlement akin to the HREOC proposal, Australian workers can gain access to paid maternity leave benefits in three ways-via collective bargaining, employment in the public sector, or working for an "enlightened" employer who sees such benefits as an element of HR strategy. While approximately two-thirds of the workforce is covered by collectively negotiated awards or agreements, only $11 \%$ of

\footnotetext{
1 HREOC is an independent statutory authority established under the Human Rights and Equal Opportunity Commission Act 1986 (Commonwealth). It has a variety of functions and powers to promote and protect the human rights of all people in Australia, one of which is to administer the Sex Discrimination Act 1984 (Commonwealth) (Sex Discrimination Unit, 2002a). There was an established precedent for HREOC to initiate enquiries of this nature, e.g., the enquiry into pregnancy (Sex Discrimination Unit, 1999), one recommendation of which was to conduct further research into the need for paid maternity leave.
} 
federal agreements and 5\% of state agreements include a paid maternity leave clause (Baird, 2003). Furthermore, about one fifth of Australian workers are classified as public sector employees (Australian Bureau of Statistics, 2003b, 2004). Even under the unrealistic assumption of a negligible intersection between the union and public sectors, private sector strategy would be left to provide 60 percent of the Australian workforce with paid maternity leave benefits. Consequently, the business case for paid maternity leave provision must be quite compelling to preclude the need for a regulatory fix.

We know of no study that isolates the impact of paid maternity leave policy on establishment or firm performance, partly because such a policy would more effectively deliver results as part of a larger patchwork of employment practices (Becker \& Huselid, 1998; MacDuffie, 1995). So called high-performance work systems (HPWS) might include an entire bundle of flexibility policies aimed at inducing attachment and other productivity-enhancing behaviours, with the ultimate goal of increasing firm performance. While Perry-Smith and Blum (2000) uncovered a link between extensive work-family policies and perceived organizational performance, other studies have found that polices aimed at increasing one's ability to coordinate work and family roles actually increase feelings of work-family conflict, especially for women (Batt \& Valcour, 2003; Williams, 2000). Furthermore, in order for paid leave provisions to generate value for the firms offering them, these policies would have to yield sustainable competitive advantage (Porter, 1985). However, without obvious impediments to labour market competitors seeking the same goal, firms will look elsewhere for strategic means to bolster performance. Theoretical and empirical accounts from conventional economics also preclude the private sector from amply providing paid maternity leave. Even those workers who value the benefit are likely to do so at levels below the full cost to employers, the latter of which includes an increment for administrative costs associated with hiring and training temporary workers (Lai \& Masters, 2005; Summers, 1989). This perceived inequality in the eyes of the immediate parties to the employment relationship should also serve to dampen the likelihood that the private sector, strategic route, will provide non-union workers outside the public sector with access to paid maternity leave. Indeed, Osterman's (1995) survey of US establishments revealed extraordinarily low incidence of work-family benefits of any sort. In the wake of this empirical and theoretical bulwark, one can only conceive that the bulk of Australian employees will not have access to paid maternity leave.

Hypothesis 1: Workers are unlikely to secure access to paid maternity leave.

In contrast to paid maternity leave, an unpaid scheme has been in place for parents of either sex for over a decade. However, a number of pressures work against employees seeking to exercise their right to unpaid parental leave. Most of these will be highlighted below with respect to specific predictors of leave use and access. Suffice it to say that one cannot overstate the power of workplace and societal norms in shaping people's choices for managing work and personal responsibilities (Williams, 2000). Perlow (1998) frames one's use of codified policies as a form of worker resistance to managerial authority, prompting many of those researching work-family issues to jettison stated policies outright, choosing instead to focus on ground level work practices (Rapoport, Bailyn, Fletcher, \& Pruitt, 2002). Others position norms related to 
workplace rewards and long-term career prospects in ways that could explain low rates of uptake (Landers, Rebitzer, \& Taylor, 1996, 1997; Perlow, 1995).

Hypothesis 2: Workers will generally not exercise their statutory right to unpaid parental leave.

A number of factors not wholly separable from the role of norms also influence one's decision to use their existing leave rights as well as the likelihood that one's employer offers a paid maternity leave option. Despite survey evidence from the US that worklife incentives matter to employees of both sexes (Towers Perrin, 2002), the system which Williams (2000) labels "domesticity" reifies the set of human behaviours that consign women to home production and men to market production. Despite their appearance, innovative policies provide little choice for working women or their spouses. Households subsisting on two incomes will rationally choose the path exacting the least long-term cost on the household. In the absence of more radical changes in the assumptions underpinning work and family, the act of exercising one's right to unpaid parental leave will levy a much greater penalty to the long-term career prospects of men than to those of women (Bailyn, 1993; Rapoport et al., 2002). Consequently, even those men wanting to accept a greater role in child-rearing recognize that doing so sends a damaging signal to their employer (Perlow, 1998), one that spurns the traditional ways men achieve success in the organization (Kanter, 1977 [1993]) and that may prove detrimental to the well-being of all members of the household.

While women may be more likely than men to use their unpaid parental leave, we cannot anticipate their having disparate access to paid maternity leave than do otherwise similar men. That is, the zero-order correlation between one's being a women and one's having access to maternity leave may well be negative, but the addition of predictors for income, occupation, and life stage will dissolve this relationship. Our reasoning stems from research on organizations that substantiates a positive relationship between firm performance and work-family human resource practices by invoking the symbolic action perspective (Pfeffer, 1981). Symbolic action theory asserts that employers take some actions in order to symbolize organizational concern, irrespective of actual content (Perry-Smith \& Blum, 2000). By providing paid maternity leave, the firm sends a powerful signal to its workforce and to recruits that it values the same things the employee values - the well-being of the employee and his or her family (Grover \& Crooker, 1995). Indeed, others have argued that goal alignment and congruence induce discretionary effort, frequently in environments where workers share in the rents accruing to improved organizational performance (MacDuffie, 1995). Still, the symbolic action perspective implies that the firm will reap the full benefits of this strategy at negligible cost if it knows that few of its employees even qualify for the benefit. The weight of this evidence does not suggest that women will be more or less likely than men to work for employers offering a paid maternity leave benefit.

Hypotheses 3a and 3b: Female employees will be no more likely to have access to paid maternity leave benefits than their male counterparts. However, female employees will be more likely than their male counterparts to have exercised their statutory right to unpaid parental leave upon the birth of their youngest child. 
We noted above that public sector workers have long had access to paid maternity leave, the specifics of which differ with respect to the level of government, e.g., commonwealth or state, and the specific Australian state employing the worker. Union membership, while not guaranteeing workers access to paid maternity leave, has been shown to provide substantial incremental entitlements not availed to non-union workers, including those that facilitate the integration of work and family responsibilities (Burgess \& Baird, 2003; McGrath-Champ, 2003). On the other hand, we would expect neither union nor public sector employment status to significantly increase the likelihood that a worker would use their existing unpaid leave. Even if workers did self-sort into unions or the public sector, they will logically exhaust their paid leave before tapping their unpaid leave. ${ }^{2}$ Moreover, nothing about either of these states counters the normative forces proscribing the use of unpaid leave.

Hypotheses $4 \mathbf{a}$ and $\mathbf{4 b}$ : Public sector workers will be more likely than private sector employees to have access to paid maternity leave benefits. However, one's employment in the public sector will not increase the likelihood of using the existing entitlement to unpaid parental leave.

Hypotheses 5a and $\mathbf{5} \mathbf{b}$ : Unionized employees will be more likely than non-union employees to have access to paid maternity leave benefits. However, one's union status will have no association with one's likelihood of using the existing entitlement to unpaid parental leave.

Industrial relations theorists have long noted that larger workplaces pay higher wages, even after controlling for a wide range of individual, human capital characteristics (Lester, 1948, 1967). Not only do these differentials persist, but similar gaps obtain for measures of employee benefits (Brown, Hamilton, \& Medoff, 1990). Brown et al. (1990) show that higher fixed costs for benefit provision and administration feed the correlation, though one could also argue that workers in large firms are made more productive by the firm's ability to bulk purchase other production inputs. Increases in firm or workplace size may also impede supervision or increase the degree of production process interdependence, both of which render generous benefits a cost-effective "carrot" for invoking worker effort and raising the cost of shirking.

We have no strong theory to suggest why establishment size should increase one's likelihood to use their unpaid parental leave, and only weak support for a negative relationship. Landers et al. $(1996 ; 1997)$ report that attorneys in large firms have more difficulty integrating work and family demands than do those in small firms, a result that they believe stems from a positive relationship between workplace size and the stringency of work and career norms. They expect that their results would generalize to other professions in which group members benefit from the productivity of others in their group, group output is highly sensitive to individual contributions, and workerspecific productivity is costly to observe. Kanter's (1977 [1993]) classic ethnographic

2 Aspects of the survey preclude a direct assessment of the ways workers integrate their unpaid and paid leave provisions. The survey did not ask about the use of the paid paternity leave provision of the respondent's present employer, nor did it ask for specific details on how many weeks of unpaid leave the employee used of their unpaid leave entitlement.

MIT Workplace Center

Working Paper \# WPC 0020 
treatment implies a similar relationship between establishment size and one's decision to even temporarily prioritize home over market production. She argued that an individual's work and career outcomes were structurally determined, depriving individuals of agency regardless of one's talent or ability. Social and behavioural homogenisation resulted from the need to make universally understood statements about one's commitment to their employer, a process one would expect to matter more in larger settings in which workers would not be expected to know many of their coworkers. Notwithstanding, too much time has passed for us to assume that Kanter's theory still holds. Even if it does, the inductive nature of her study did not allow her to test specific hypotheses regarding firm size. Moreover, both Landers et al. $(1996 ; 1997)$ and Kanter neglect manufacturing. However, one recent study focusing exclusively on US manufacturing found no relationship whatsoever between establishment size and workers' perceptions that their employer facilitates the balancing of work and family responsibilities (Berg, Kalleberg, \& Appelbaum, 2003). ${ }^{3}$

Hypotheses 6a and $\mathbf{6 b}$ : The size of both the employee's establishment and the larger organization of which that establishment is a subunit will positively predict a worker's access to paid maternity leave. However, the effects of workplace and organizational size on the use of the unpaid parental benefit will be ambiguous.

The theoretical basis for what economists call the "labour supply decision" proves useful for theorizing the relationship between earnings and one's decision whether or not to use their unpaid leave. Economists abstract a person's decision to work an additional hour by positioning it as a choice between an additional unit of consumption goods or an additional unit of leisure, the latter of which is unavailable to those choosing not to supply another hour of labour. Holding all other factors constant, an increase in the wage rate motivates the worker to substitute away from leisure and into work, what labour economists call the "substitution effect." On the other hand, as a worker's wealth increases, additional increments to net personal assets enable the worker to substitute away from work and into leisure or home production, what economists label the "income effect" (Cahuc \& Zylberberg, 2004). ${ }^{4}$ Thus, the curve describing the emergent relationship between income and hours worked bends backward over itself. At the lowest income levels, increases in wages induce additional time at work, until a certain point at which the income effect dominates the substitution effect. While much of neoclassical economics theory proves too abstract to be credibly applied, newly-minted parents indeed face an allocation decision between consumption goods and child-rearing time. Indeed, any parent will attest that newborns demand quite a bit of both.

\footnotetext{
${ }^{3}$ While size measures frequently emerge as significant predictors of labour market and organizational phenomena, Berg et al.'s (2003) results make sense when the dependent variable captures use as opposed to access or availability. Theory from the economics, sociology, and organizations literatures can all be called upon explain why large firms would be more likely than smaller ones to offer a particular employee benefit (e.g., Baron, Dobbin, \& Jennings, 1986; Brown et al., 1990; DiMaggio \& Powell, 1993; Pfeffer, 1981). However, workplace-grounded research from the industrial relations and work-family perspectives stresses the discrepancy between formal access to "family-friendly" benefits and a true, "felt" availability or "usability" of these benefits in the minds of workers (Eaton, 2003).

${ }^{4}$ For a non-technical treatment and illustration, see Ehrenberg and Smith (2003).
} 
Where conventional economics falls short is in its incorporation of norms. In her explanation of domesticity and its impact on the behaviour of both male and female workers, Williams (2000) claims that men and women face different expectations in the labour market, expectations that penalize men more severely than women for appearing to have prioritised child-rearing over work. Thus, relative to the women's labour supply choice, the male's decision to use his unpaid leave should be insensitive to income.

In contrast to the use of unpaid leave, one's access to paid maternity leave should bear little relation to one's annual income. The notion of a positive relationship between a worker's income and his or her access to paid leave withers in the wake of theoretical and empirical evidence favouring compensating wage differentials, particularly with respect to maternity benefits (Gruber, 1994; Lai \& Masters, 2005). This literature implies that for those that fully value paid maternity leave, wages will actually fall to offset the cost of the benefit to the employer, resulting in a negative relationship between income and probability of access to paid leave. However, this perspective falsely assumes that wages are determined like commodity prices, ignoring the many institutional facets of wage determination. Given that wages are generally not renegotiated on an individual basis, employers would be loath to introduce a maternity benefit, the exercise of which would reorder workplace compensation structures. Consequently, the highly-paid would be no more likely to have access to paid maternity leave than the low-paid.

Hypotheses $\mathbf{7 a}, \mathbf{7 b}$, and $\mathbf{7 c :}$ The relationship between a worker's income level and his or her likelihood to have access to paid maternity leave will be indeterminate, irrespective of sex. However, the effect of income will be to increase the likelihood that one availed themselves of their unpaid parental leave upon the birth of their youngest child. Moreover, this income effect will be greater for women than for men.

Those seeking to integrate work and family responsibilities must contend with the unfortunate reality that the most formative years for determining one's career path coincide with those years when parental and other familial responsibilities are at their peak. This has implications for both the use of unpaid parental leave and access to paid maternity leave. With respect to the latter, men and women in this stage of their lives will likely sort themselves into workplaces that offer a paid maternity leave benefit. Workers will value the option to use the program at some point in the future. Moreover, employers acting strategically will recognize the power of paid maternity leave for screening applicants and inducing discretionary effort (Perry-Smith \& Blum, 2000). Notwithstanding, the impression created by workers early in their careers is a lasting one, underlining the need to send signals of commitment as soon as they embark on their career path. As a result, workers will often avoid exercising their right to family-friendly policies for fear of career marginalization (Hochschild, 1997). First, this mechanism operates in such a way as to dissuade workers from actually using these policies, suggesting that being in the child-bearing/career-building stage of one's life will not impact one's likelihood to use their unpaid parental leave. Second, as noted above, the very fact that family-friendly policies will be so undersubscribed encourages many employers to offer them in the first place. We would also expect these processes 
to materialize even more so for managers and professionals than for others. For these occupational types, family-friendly policies provide an inside-the-firm mechanism for sorting those on the "fast track" from those on the "mommy track" (Hochschild, 1997; Kanter, 1977 [1993]; Landers et al., 1996, 1997; Williams, 2000).

Hypotheses 8a, 8b, and 8c: A worker in the child-bearing/careerbuilding life stage will be more likely than others to have access to paid maternity leave, irrespective of one's sex. However, he or she will be no more likely than others to have used their unpaid parental leave upon the birth of their youngest child.

Hypotheses 9a and 9b: Managers and professionals will be more likely than others to work for an employer offering a paid maternity leave benefit, irrespective of one's sex. However, one's occupational type will not increase one's likelihood to have used their unpaid parental leave benefit.

\section{Methods}

These hypotheses were tested with data from a nationwide survey of employed members of the Australian labour force, conducted by telephone in November 2002 for the "World of Work" Research Cluster at the University of Sydney. Data collectors relied on a computer-aided telephone interviewing (CATI) system that gathered demographic and behavioural information for each respondent, including whether or not the respondent had children, and if so, whether or not he or she used unpaid parental leave. The survey also captured characteristics of the respondent's present employer, including whether or not the employer offers any form of paid maternity leave to female employees.

\section{Survey}

The survey underpinning this paper is part of a wider study of parental and family leave in Australia. The parental and family leave questions complement previous work by Baird, Brennan, and Cutcher (2002) and Baird (2003) on the availability of paid maternity leave in Australia. The resulting dataset contains 1,032 observations of employed Australians ages 15 and up. We stratified the sample by state of residence, invoking an iterative weighting procedure to ensure the sample's representativeness of the employed side of the Australian workforce (Reiter, Zanutto, \& Hunter, forthcoming).

\section{Variables}

For this survey, researchers asked directly about the availability of paid maternity leave and about the use of unpaid parental leave at the birth of the respondent's youngest child. Unfortunately, due to space restrictions, questions about the use of paid maternity 
leave, paid paternity leave, and the specific number of weeks of unpaid leave used were not asked in this survey. ${ }^{5}$ Surveyors, however, did ask whether or not the respondent's youngest child was 10 years of age or younger. Having a child born in the last decade ensures that these parents were eligible for unpaid parental leave at the time of this particular child's birth. Consequently, PAID MATERNITY LEAVE and UNPAID PARENTAL LEAVE are the binary dependent variables that this study will model. The variable CHILD UNDER 10 will enable us to manage issues of selection and missing data. Those without a child under 10 did not have a statutory right to unpaid parental leave, systematically yielding a zero value for UNPAID PARENTAL LEAVE. The means, standard deviations, and descriptions for these and the other variables appear in Table 1. We report descriptive statistics, mainly means and pair-wise correlations, using weighted data, but all subsequent model estimation ignores weighting. ${ }^{6}$

The remaining variables in Table 1 are those predictors required to test the specific hypotheses enumerated above. Each of these binary measures were obtained using the same survey. FEMALE captures the sex of the respondent, which will be important both as a main effect and in its interactions with four other variables-MIDDLE INCOME, HIGH INCOME, LIFE STAGE, and MANAGER. With respect to income, the lowest income category, those earning less than AU\$40,000 per year, has been omitted. This categorical division allows one to think of the intermediate bin as containing the median employee with respect to annual income (Australian Bureau of Statistics, 2003a), with additional bins for the wealthiest and poorest members of the labour force. LIFE STAGE captures whether or not the respondent is between the ages of 25 to 44, considered to be the pivotal years for career- and family-building. The variable MANAGER equals one for those whose current job is classified into one of two single-digit categories in the Australian Standard Classification of Occupations, $2^{\text {nd }}$ Edition (ASCO2) _ "Managers and Administrators" or "Professionals."

The categories for workplace size, measured by the number of employees, were established analogously to those capturing income. The variable representing the smallest workplaces serves as the referent category. Following Osterman (1995), the effects of firm as opposed to establishment size will be isolated with the variable ORGANIZATIONAL SUBUNIT. ORGANIZATIONAL SUBUNIT equals one in cases where the total number of workers employed by the firm in Australia is greater than the number of workers in the respondent's place of work. Finally, UNION and PUBLIC SECTOR mark a respondent's union status and whether or not he or she works in the public sector, respectively.

\footnotetext{
${ }^{5}$ A more comprehensive survey soliciting more information along these lines is underway. For further details, see Whitehouse, Baird, Diamond, \& Soloff (forthcoming).

${ }_{6}$ The linearity assumptions inherent in OLS and logistic regression have traditionally justified the use of unweighted data for these estimators. However, groundbreaking work by Reiter, Zanutto, and Hunter (forthcoming) suggests both design-based and survey-weighted alternatives to the conventional approach applied in this paper.
} 


\section{Results}

Table 2 displays the intercorrelations of the variables and Tables 3 and 4 provide the fitted parameters for two sets of hierarchical logistic regression analyses. Table 3 shows estimates for the likelihood that an employee has access to paid maternity leave in the workplace while Table 4 fits the same explanatory variables to predict whether or not a respondent exercised his or her statutory right to unpaid parental leave upon the birth of their youngest child. Both theoretical and statistical considerations justify our decision to pool the sample by sex and insert two-way interactions for predictors hypothesised to differ by sex. The choice of logistic regression over a probit estimate was arbitrary. However, the estimates were not sensitive to the choice of functional form.

While the full sample consisted of $n=1,032$ observations, estimates for UNPAID PARENTAL LEAVE relied on a much smaller Subsample of $n=356$. This reflects the underlying logic that those respondents without children 10 or younger would not have had any universal entitlement to exercise. Thus, most of those with "missing" answers to this question were logically and intentionally precluded from answering it. A separate challenge arises when estimating one's likelihood to have access to paid maternity leave in his or her workplace, winnowing the sample size down to $n=766$. In this case, however, every respondent is "eligible" to be aware of his or her employee benefits, irrespective of one's family structure. No pattern was immediately observable in the sex or parental status of these "non-responders," the latter assessed with the variable CHILD UNDER 10. Unreported statistical tests reject sample selection as a source of bias for our estimates of unpaid leave use and support the notion that the missing values for PAID MATERNITY LEAVE do not reflect a systematic and predictable ignorance that might afflict our estimates. ${ }^{7}$

Results for paid leave show that $60 \%$ of Australian employees work for an employer who provides some form of paid maternity scheme, indicated by the value for the logit transformation for the estimated null model. ${ }^{8}$ Interestingly, the addition of an explanatory variable capturing the main effect of sex does not alter these findings since

\footnotetext{
7 To determine whether or not our estimates were plagued by selection bias, we re-estimated the equations from Table 4 using the binary equivalent of the Heckman selection correction (Heckman, 1976, 1979; van de Ven \& van Praag, 1981). Notwithstanding the onerous structural assumptions one must make in order to accept these unreported estimates, we believe they bolster the results displayed in Table 4. Assuming that respondents were self-selecting based on their sex and whether or not they had a child under the age of 10 did not alter the parameter estimates in any material way. Furthermore, in no case could we reject the null hypothesis that the joint likelihood of the independent probit model for the selection equation and an unreported probit estimation for those workers actually observed was in fact, equal to zero. With respect to our predictions for access to paid leave, observability could not be predicted by one's sex or by whether or not one had a child, demonstrated via tests of independence and another application of the van de Ven \& van Praag (1981) algorithm.

${ }^{8}$ Logistic regression enables the linear estimation of a dependent variable, but does so at the cost of complicating the interpretation of the magnitude of the parameter estimates. Since this calculation comes from the null model, it can be undertaken without making any assumptions about other variables. In this case, $\hat{p}=\frac{1}{1+e^{-\left(\beta_{0}\right)}}=\frac{1}{1+e^{-(0.40)}}=0.60$. The addition of explanatory variables complicates the backing out of fitted probabilities.
} 
the negative coefficient on FEMALE is insignificantly different from zero. This finding disposes of the simple assessment that women have less access to their own paid leave provisions than do their male counterparts. However, the addition of an explanatory variable for public sector employment in $\mathrm{M} 2$ not only provides strong support for hypothesis 4a, but offers the empirical underpinnings for the claim that workplace and institutional characteristics moderate the relationship between demographic qualities and access to paid maternity leave. Employment in the public sector increases the probability that one will have access to paid leave. When considered in the context of the positive, pair-wise correlation between public sector employment and sex shown in Table 2, the statistically significant, negative coefficient on FEMALE in M2 implies that women outside the public sector are less likely than men to have access to a paid maternity leave provision. Similarly, controlling for union membership in M3 leaves the qualitative impact of sex unchanged, since the correlation between sex and union status reported in Table 2 is near nil. Similar logic accounts for the effects of firm and workplace size on one's access to paid maternity leave as captured by M4 and M5. The main effect of sex permanently succumbs to collinearity with the inclusion of ORGANIZATIONAL SUBUNIT. Collective bargaining coverage associates positively with one's likelihood to access to paid maternity leave, as does the size of the employing firm and the number of employees in an employee's workplace, sustaining hypotheses 5 a and 6 a.

Income does not appear to have an effect on a worker's access to paid maternity leave for either men or women, buttressing hypothesis $7 \mathrm{a}$. The insignificant $\chi^{2}$ value for these incremental regressors, captured in M6 and M7, implies that the incorporation of income measures does not deliver a meaningful increase in model fit, even when this income effect can differ by sex. The next two models, M8 and M9 incorporate measures of the effect of a worker's life stage. The positive coefficient on LIFE STAGE in M8 suggests that those workers most expected to benefit from paid maternity leave are, indeed, matched to employers who provide this benefit. However, the addition of the two-way interaction between FEMALE and LIFE STAGE reveals that the positive association exists mainly for men. In one sense, these parameter estimates square with hypotheses $8 \mathrm{a}$ and $8 \mathrm{~b}$, since the effect of LIFE STAGE does not appear to differ for women. However, summing the main and interaction effects reveals scant evidence that those women in the most formative years for building families and careers are being served at all by existing arrangements for the provision of paid maternity leave. ${ }^{9}$ The last two models in Table 3, M10 and M11 address hypothesis 9a by adding binary variables for the main effect of being a manager or professional as well as a two-way interaction between managerial or professional status and sex. Just as hypothesized, managers and professionals are indeed more likely than others to benefit from an employer-provided paid maternity leave benefit. However, the effect appears not to differ by sex.

With respect to workers' use of unpaid parental leave, Table 1 implies that $27 \%$ of those workers eligible actually availed themselves of their unpaid leave benefit upon the birth

${ }^{9}$ The total effect of LIFE STAGE for women is the linear combination of the main effect of LIFE $S T A G E$ and the coefficient describing the differential effect for women. Thus, $\hat{\beta}_{\text {LIFE STAGE }}+\hat{\beta}_{\text {FEMALEXLIFE STAGE }}=0.66-0.53=0.13$ with $p \approx 0.54$. 
of their youngest child. ${ }^{10}$ Table 4 displays logit estimates for a series of nested models in which UNPAID PARENTAL LEAVE is the dependent variable. The main effect of FEMALE, first inserted in $\mathrm{M} 1$, is positive and statistically significant. Moreover, this effect persists despite the addition of controls for public sector and union status and workplace and firm size. For models M1 - M5, one's sex is the only statistically significant predictor of leave use, marshalling evidence in support of hypotheses $3 \mathrm{~b}, 4 \mathrm{~b}$, $5 \mathrm{~b}$, and $6 \mathrm{~b}$. Women are more likely to use their unpaid parental leave than are men, and patterns of leave use do not appear markedly different for those workers counted as union members or public servants. Similarly, those labouring in medium or large workplaces do not use their unpaid leave entitlement any more than those employees in smaller workplaces.

Measures of income appear in M6, with estimates fully consistent with hypothesis $7 \mathrm{~b}$. Relative to those with income below the median, those in the middle and highest income categories appear more likely to have used their unpaid parental leave. Moreover, the transition from M5 to M6, representing the addition of the two main effects of income, engendered a sizable increase in the parameter estimate attached to FEMALE. When considered in combination with the negative correlation between FEMALE and both income dummies, revealed in Table 2 , these results suggest that earlier estimates of the effect of sex were actually biased toward zero by the omission of controls for income. Once we account for income, the differential likelihood that women will use their leave relative to men grew. In $\mathrm{M} 7$, the addition of two, two-way interaction variables allows the income effect to differ by sex. With this move, sex ceases to be a statistically significant predictor of leave use, though it remains positively associated with the dependent variable. Income becomes the only discernable driver of leave use. However, the entire income effect comes from female employees. Both main effects effectively become zero, while the fitted coefficients for FEMALE $\times$ MIDDLE INCOME and FEMALE $\times$ HIGH INCOME enter the analysis as positive predictors of leave use. These models shore up hypothesis $7 \mathrm{c}$, but undermine the claims of hypothesis $7 \mathrm{~b}$. Allowing the effect of income to differ by sex, income no longer appears to have any effect on the leave decisions of men. Notice also that neither one's life stage nor their status as a manager or professional has a clear relationship with whether or not one takes leave, irrespective of the worker's sex, lending support to hypotheses $8 \mathrm{c}$ and $9 \mathrm{~b}$.

Three hypotheses remain unaddressed. Hypothesis 1 called for an unconditionally, low probability that workers could secure access to paid maternity leave. At first pass, Table 1, which estimated that $60 \%$ of Australian employees had access to paid maternity leave, made the likelihood of upholding this hypothesis rather low. Table 5 offers a more nuanced perspective by providing fitted prototypical probabilities based on the final model of Tables 3 and 4. From the top half of Table 5, we can see that public sector employment and collective bargaining succeed in delivering a paid maternity

\footnotetext{
${ }^{10}$ In contrast to the analogous calculation made for the null model of paid maternity leave, the value derived from the logistic transformation and the value that appear in Table 1 differ slightly. The descriptive statistics reported in Table 1 reflect design-based weighting, whereas unweighted data are more appropriate for inferential, linear modelling. The sample mean for UNPAID PARENTAL LEAVE, when calculated with the unweighted data using the transformation described in footnote 5 , is 0.32 . In the case of the variable PAID MATERNITY LEAVE, the application of frequency weights left the mean estimator unchanged.
} 
leave option to Australian workers. Women positioned in the intersection of union membership and public service have 0.78 probability of having access to paid maternity leave, just under the 0.84 likelihood that otherwise identical male employees work in establishments offering this benefit. However, notice that for those in the private sector who are not able to get under the union umbrella, particularly women, the probability of having access to paid maternity leave falls to less than half. Even these women should consider themselves fortunate. Table 5 assumes that each of the predictors of leave status aside from sex, union status, and sector, sits at its sample mean. For those private sector, non-union, non-managerial women working at the smallest workplaces with the lowest incomes, their probability of access to paid maternity leave falls below 0.20. Consequently, while we cannot claim to have disposed of hypothesis 1 altogether, the modelling exercise has revealed tremendous variation in patterns of maternity leave access. Quite of few of these configurations yield very low probabilities of access to paid maternity leave.

Table 5 also addresses hypothesis 3 a which predicted that women would not have greater access than men to paid maternity leave. No scenario in Table 5 insinuates a probability gap of less than 0.06, a difference that obtains for unionized, public sector workers. Finally, hypothesis 2 predicted low rates of uptake for unpaid parental leave, a proposition generally upheld by the data. According to the bottom half of Table 5, the probability that women workers will use their unpaid leave never quite reaches 0.50 , still double the rate of otherwise identical men. Furthermore, the parameter estimates in Table 4 suggest that only income appears to predict the likelihood of unpaid leave use, and that this "income" effect obtains only for women.

\section{Discussion}

These results provide valuable lessons for Australian policymakers as they consider HREOC's proposed scheme, but more broadly, for lawmakers, managers, and others in industrial economies where full-time workers must self-negotiate the integration of work and family. The public sector has reliably supplied the labour market with paid maternity leave. However, our findings in this respect highlight that access to an employment policy with direct benefits to working women and indirect benefits to society-at-large (Gornick \& Meyers, 2003) has yet to transcended government employment. Furthermore, widespread privatisation campaigns across the public sector render even this trusted provider vulnerable to the vicissitudes of deregulated markets (Baird, 2003).

Paid maternity leave has also manifested itself in the trade union bargaining agenda, evidenced in our study as well as earlier qualitative investigations (Baird et al., 2002; Burgess \& Baird, 2003). For example, the Public Service Association in New South Wales, the Australian Manufacturing Workers Union, and the National Tertiary Education Union have all lodged claims for improvements in paid maternity leave entitlements for their members.

Outside of these two options, both of which face obstacles just to conserve their existent institutional hold in the labour market, women have little chance of securing access to 
paid maternity leave. While the public sector did set high standards early, paid leave provisions have failed to diffuse throughout the private sector in the very same period that women's participation in the paid workforce has increased so dramatically. Our results indicate that company policy in the private sector has not had a significant impact on the availability of paid maternity leave, despite notable, recent examples underscoring both the business and worker cases for this class of benefit (e.g., The Australian Catholic University and Holden Australia). Unless more of these highly visible examples change the limited pattern of diffusion experienced in the past and lead to a new, accelerated proliferation of benefits, collective bargaining or company initiatives will not produce widespread access to paid maternity leave. In this respect, our findings accord with existing theory. Individual employers have a number of legitimate reasons for opting not to offer paid maternity benefits on their own. Employees may value the benefit, but not by the full amount of foregone wages that a such an entitlement yields. However, this should not imply support for the unregulated view - that if employers and employees value the benefit they would be able to negotiate it on an individual or even firm-wide basis. A number of researchers have postulated theories of market failure - that the costs of work-family benefits exceed the private benefits, but that additional benefits accrue on a society-wide basis when parents are better able to perform their dual role (Drago \& Hyatt, 2003; Gornick \& Meyers, 2003). Thus, even for those privileging economic efficiency over other social and employment objectives, work-family researchers offer a wealth of examples that justify increased government expenditure (e.g., Calman \& Tarr-Whelan, 2005).

The policy void generated by the under-provision of a paid maternity leave has not been filled by those choosing instead to use unpaid parental leave. The analysis suggests that the unpaid parental leave provision which has been available to Australian employees for a decade is rarely utilized, particularly by men. The "new-age father," sharing childrearing responsibilities in the first year of a child's life, has not arrived in the Australian workplace, squaring with the behaviour of male workers in the US (Commission on Family and Medical Leave, 1996). On the one hand, this suggests that women absorb a disproportionate share of the costs of parenting, a notion at least as old as the industrial revolution (Williams, 2000). However, employed male fathers are not the sole culprits, as they recognize that they will be penalized more for labour market intermittency than will women (Polachek \& Siebert, 1993; Rapoport et al., 2002). In this context of constrained employment and benefit options, men and women who behave conventionally are acting in the best interests of their household and their children, albeit succumbing to labour market constraints that policy could well alleviate.

The analysis also reveals that many women cannot afford to take time off from work. Most critically for the debate about the provision of paid maternity leave in Australia, the results show that low income does not arise as a compensating wage differential for access to paid maternity leave. Low-income women have no more access to paid maternity leave than do their more highly paid counterparts, an implication of there being no discernible relationship between income and leave access after controlling for sex, union and sector status, and workplace size. Moreover, low-income women are less able to use their unpaid maternity leave entitlement than either more highly-paid women or men at any pay level. In fact, any evidence that women exercise this statutory right more than men holds exclusively for those earning above the median 
level of income. Thus, motherhood in the wake of paid employment only reinforces an already tenuous economic position and weak attachment to the labour market, exacting present and future indirect costs on children and society. HREOC's recommendation of a scheme that provides minimum wage replacement for all women taking maternity leave from work would help these low-income women directly. It would also benefit, albeit at a minimum wage level, all 700,000 working women in Australia who do not have access to paid maternity leave.

Finally, that the survey results suggest an overall low utilization of unpaid parental leave raises questions about the real value of the legislative provision. If it is intended to be more than rhetoric for work and family policy, then there should be concern about its lack of use (Eaton, 2003). Taken together, these data suggest that in the absence of either legislation or an award that covers large segments of working women, access to paid maternity leave will be limited to those in the public sector, those who are union members, and those working in larger workplaces and organizations.

\section{Conclusion}

The debate about paid maternity leave in Australia highlighted the need for more research on the broad topic of parental leave, including both paid and unpaid maternity leave. Although unpaid parental leave is legislated, there appears to be only infrequent use of the leave, especially among men. Furthermore, while legislation for paid maternity leave remains restricted to the public sector, our analysis confirms that neither collective bargaining nor the individual choices of employers effectively broaden access to paid maternity leave. Unions deliver results, but do not succeed in covering the bulk of private sector employed women. The policy implications of these results are now quite clear. If the HREOC recommendations are not implemented, the most needy players in the labour market-low-paid, non-unionized, private sector, female employees - will continue to be denied access to paid maternity leave and the ability to exercise their right to even unpaid parental leave.

\section{Acknowledgements}

This paper benefited from the generous support of the MIT Workplace Centre as well as the advice of Sue Bearfield. The authors take responsibility for all remaining errors and omissions. 


\section{References}

Australian Bureau of Statistics. (2003a). Average Weekly Earnings (No. 6302.0). Canberra: ABS.

Australian Bureau of Statistics. (2003b). Wage and Salary Earners, Public Sector, Australia (No. 6248.0). Canberra: ABS.

Australian Bureau of Statistics. (2004). Employee Earnings and Hours, Australia (No. 6306.0). Canberra: ABS.

Australian Department of Employment and Workplace Relations. (2001). personal communication with Marian Baird.

Bailyn, L. (1993). Breaking the mold: Women, men, and time in the new corporate world. New York: Free Press.

Baird, M. (2003). Paid maternity leave: The good, the bad, the ugly. Australian Bulletin of Labour, 29(1), 97-109.

Baird, M., Brennan, D., \& Cutcher, L. (2002). A pregnant pause: Paid maternity leave in Australia. Labour \& Industry, 13(1), 1-19.

Baron, J. N., Dobbin, F. R., \& Jennings, P. D. (1986). War and peace: The evolution of modern personnel administration in US industry. American Journal of Sociology, 92(2), 350-383.

Batt, R., \& Valcour, P. M. (2003). Human resource practices as predictors of workfamily outcomes and employee turnover. Industrial Relations, 42(2), 189-220.

Becker, B. E., \& Huselid, M. A. (1998). High performance work systems and firm performance: A synthesis of research and managerial implications. Research in Personnel and Human Resources Management, 16, 53-101.

Berg, P., Kalleberg, A. L., \& Appelbaum, E. (2003). Balancing work and family: The role of high-commitment environments. Industrial Relations, 42(2), 168-188.

Brown, C., Hamilton, J., \& Medoff, J. L. (1990). Employers large and small. Cambridge, MA: Harvard University Press.

Burgess, J., \& Baird, M. (2003). Employment entitlements: Development, access, flexibility, and protection. Australian Bulletin of Labour, 29(1), 1-13.

Cahuc, P., \& Zylberberg, A. (2004). Labor economics. Cambridge, MA: MIT Press.

Calman, L. J., \& Tarr-Whelan, L. (2005). Early childhood education for all: A wise investment. New York: Legal Momentum. 
Commission on Family and Medical Leave. (1996). A workable balance: Report to congress on family and medical leave policies: United States Department of Labor.

DiMaggio, P., \& Powell, W. W. (1993). The iron cage revisited: Collective rationality and institutional isomorphism in organizational fields. American Sociological Review, 48, 147-160.

Drago, R., \& Hyatt, D. (2003). Symposium: The effect of work-family policies on employees and employers. Industrial Relations, 42(2), 139-144.

Eaton, S. C. (2003). If you can use them: Flexibility policies, organizational commitment, and perceived performance. Industrial Relations, 42(2), 145-167.

Ehrenberg, R. G., \& Smith, R. S. (2003). Modern labor economics: Theory and public policy (8th ed.). Reading, MA: Addison-Wesley.

Glezer, H. (1988). Maternity leave in Australia: Employee and employer experiences. Melbourne: Australian Institute of Family Studies.

Gornick, J. C., \& Meyers, M. (2003). Families that work: Policies for reconciling parenthood and employment. New York: Russell Sage Foundation.

Grover, S. L., \& Crooker, K. J. (1995). Who appreciates family-responsive human resource policies: The impact of family-friendly human resource policies on the organizational attachment of parents and non-parents. Personnel Psychology, 48(2), 271287.

Gruber, J. (1994). The incidence of mandated maternity benefits. American Economic Review, 84(3), 622-641.

Heckman, J. J. (1976). The common structure of statistical models of truncation, sample selection and limited dependent variables and a simple estimator for such models. Annals of Economic and Social Measurement, 5, 475-492.

Heckman, J. J. (1979). Sample selection bias as a specification error. Econometrica, 47(1), 153-161.

Heymann, J., Earle, A., Simmons, S., Breslow, S. M., \& Kuehnhoff, A. (2004). Work, family, and equity index: Where does the United States stand globally? Boston: Project on Global Working Families, Harvard School of Public Health.

Hochschild, A. R. (1997). The time bind: When work becomes home and home becomes work. New York: Metropolitan Books.

Kanter, R. M. (1977 [1993]). Men and women of the corporation. New York: Basic Books.

Kearney, S. (2002, June 2). Lin slams pay for mums push. Sunday Mail, p. 15. 
Lai, Y.-C., \& Masters, S. (2005). The effects of mandatory maternity and pregnancy benefits on women's wages and employment in Taiwan, 1984-1996. Industrial and Labor Relations Review, 58(2), 274-281.

Landers, R. M., Rebitzer, J. B., \& Taylor, L. J. (1996). Rat race redux: Adverse selection in the determination of work hours in law firms. American Economic Review, 86(3), 329348.

Landers, R. M., Rebitzer, J. B., \& Taylor, L. J. (1997). Work norms and professional labor markets. In F. D. Blau \& R. G. Ehrenberg (Eds.), Gender and family issues in the workplace (pp. 166-202). New York: Russell Sage.

Lester, R. (1948). Company wage policies: A survey of patterns and experience. Princeton: Princeton University, Industrial Relations Section.

Lester, R. (1967). Pay differentials by size of establishment. Industrial Relations, 7(1), 5767.

MacDuffie, J. P. (1995). Human-resource bundles and manufacturing performance: Organizational logic and flexible production systems in the world auto industry. Industrial and Labor Relations Review, 48(2), 197-221.

McGrath-Champ, S. (2003). Employment benefits in enterprise agreements: An overview. Australian Bulletin of Labour, 29(1), 46-61.

Osterman, P. (1995). Work/family programs and the employment relationship. Administrative Science Quarterly, 40(4), 681-700.

Perlow, L. A. (1995). Putting the work back into work/family. Group E Organization Management, 20(2), 227-239.

Perlow, L. A. (1998). Boundary control: The social ordering of work and family time in a high-tech corporation. Administrative Science Quarterly, 43(2), 328-357.

Perry-Smith, J. E., \& Blum, T. C. (2000). Work-family human resource bundles and perceived organizational performance. Academy of Management Journal, 43(6), 1107-1 117.

Pfeffer, J. (1981). Management as symbolic action: The creation and maintenance of organizational paradigms. In L. L. Cummings \& B. M. Staw (Eds.), Research in organizational behavior (Vol. 3, pp. 1-52). Greenwich, CT: JAI Press.

Polachek, S. W., \& Siebert, W. S. (1993). The economics of earnings. New York: Cambridge University Press.

Porter, M. E. (1985). Competitive advantage: Creating and sustaining superior performance. New York: Free Press.

Rapoport, R., Bailyn, L., Fletcher, J. K., \& Pruitt, B. H. (2002). Beyond work-family balance: Advancing gender equity and workplace performance. San Francisco: Jossey-Bass. 
Reiter, J. P., Zanutto, E., \& Hunter, L. W. (forthcoming). Analytical modeling in complex surveys of work practices. Industrial and Labor Relations Review.

Sex Discrimination Unit. (1999). Pregnant and productive: It's a right not a privilege to work while pregnant (interim paper). Sydney: Australia Human Rights and Equal Opportunity Commission (HREOC).

Sex Discrimination Unit. (2002a). A time to value: Proposal for a national paid maternity leave scheme. Sydney: Australia Human Rights and Equal Opportunity Commission (HREOC).

Sex Discrimination Unit. (2002b). Valuing parenthood: Options for paid maternity leave (interim paper). Sydney: Australia Human Rights and Equal Opportunity Commission (HREOC).

Summers, L. H. (1989). Some simple economics of mandated benefits. American Economic Review Papers and Proceedings, 79(2), 177-183.

Towers Perrin. (2002). Talent report 2001: New Realities in today's workforce. New York: Towers Perrin.

van de Ven, W. P. M. M., \& van Praag, B. M. S. (1981). The demand for deductibles in private health insurance: A probit model with sample selection. Journal of Econometrics, 22(3), 229-252.

Whitehouse, G., Baird, M., Diamond, C., \& Soloff, C. (forthcoming). Parental leave in Australia: Beyond the statistical gap. Journal of Industrial Relations.

Williams, J. (2000). Unbending gender: Why family and work conflict and what to do about it. New York: Oxford University Press. 
Table 1. Summary statistics and description for dependent and independent variables.

\begin{tabular}{|c|c|c|}
\hline Variable & $\begin{array}{c}\text { Mean } \\
(\mathbf{s d})\end{array}$ & Description \\
\hline PAID MATERNITY LEAVE & $\begin{array}{r}0.60 \\
(0.02)\end{array}$ & $\begin{array}{l}\text { paid maternity leave (of any kind) is available to female employees at the } \\
\text { respondent's workplace }\end{array}$ \\
\hline UNPAID PARENTAL LEAVE & $\begin{array}{r}0.27 \\
(0.03)\end{array}$ & respondent took unpaid paternity/maternity leave for his/her youngest child \\
\hline CHILD UNDER 10 & $\begin{array}{r}0.24 \\
(0.02)\end{array}$ & respondent has a child ten years old or younger \\
\hline FEMALE & $\begin{array}{r}0.44 \\
(0.02)\end{array}$ & respondent is female \\
\hline PUBLIC SECTOR & $\begin{array}{r}0.30 \\
(0.02)\end{array}$ & respondent works in the public sector \\
\hline UNIONIZED & $\begin{array}{r}0.30 \\
(0.02)\end{array}$ & respondent is a member of a trade union \\
\hline MEDIUM-SIZED WORKPLACE & $\begin{array}{r}0.45 \\
(0.02)\end{array}$ & $\begin{array}{l}10-100 \text { people work in respondent's workplace (relative to a workplace with } \\
<10 \text { workers) }\end{array}$ \\
\hline LARGE WORKPLACE & $\begin{array}{r}0.26 \\
(0.02)\end{array}$ & $\begin{array}{l}101 \text { or more people work in respondent's workplace (relative to a workplace } \\
\text { with }<10 \text { workers) }\end{array}$ \\
\hline ORGANIZATIONAL SUBUNIT & $\begin{array}{r}0.61 \\
(0.02)\end{array}$ & $\begin{array}{l}\text { workplace is part of a larger organization operating multiple workplaces in the } \\
\text { country }\end{array}$ \\
\hline MIDDLE INCOME & $\begin{array}{r}0.28 \\
(0.02)\end{array}$ & $\begin{array}{l}\text { respondent's gross annual income from paid employment is } \mathrm{AU} \$ 40,000 \text { to } \\
\mathrm{AU} \$ 70,000 \text { (relative to an annual income below } \mathrm{AU} \$ 40,000 \text { ) }\end{array}$ \\
\hline HIGH INCOME & $\begin{array}{r}0.07 \\
(0.01)\end{array}$ & $\begin{array}{l}\text { respondent's gross annual income from paid employment exceeds AU } \$ 70,000 \\
\text { (relative to an annual income below AU } \$ 40,000 \text { ) }\end{array}$ \\
\hline FEMALE $x$ MIDDLE INCOME & $\begin{array}{r}0.08 \\
(0.01)\end{array}$ & $\begin{array}{l}\text { respondent is female and her gross annual income from paid employment is } \\
\text { AU } \$ 40,000 \text { to } \operatorname{AU} \$ 70,000\end{array}$ \\
\hline FEMALE $x$ HIGH INCOME & $\begin{array}{r}0.01 \\
(0.00)\end{array}$ & $\begin{array}{l}\text { respondent is female and her gross annual income from paid employment } \\
\text { exceeds AU } \$ 70,000\end{array}$ \\
\hline LIFE STAGE & $\begin{array}{r}0.49 \\
(0.02)\end{array}$ & respondent is in the child-bearing cohort, i.e., 25 - 44 years of age \\
\hline FEMALE $x$ LIFE STAGE & $\begin{array}{r}0.21 \\
(0.01)\end{array}$ & respondent is female and in the child-bearing cohort, i.e., $25-44$ years of age \\
\hline MANAGER & $\begin{array}{r}0.27 \\
(0.02)\end{array}$ & $\begin{array}{l}\text { respondent's current job falls into the "Managers and Administrators" or } \\
\text { "Professionals" single-digit category in the Australian Standard Classification } \\
\text { of Occupations, 2nd Edition (ASCO2) }\end{array}$ \\
\hline FEMALE $x$ MANAGER & $\begin{array}{r}0.12 \\
(0.01)\end{array}$ & $\begin{array}{l}\text { respondent is female and her current job falls into the "Managers and } \\
\text { Administrators" or "Professionals" single-digit category of the Australian } \\
\text { Standard Classification of Occupations, 2nd Edition }(\operatorname{ASCO} 2)\end{array}$ \\
\hline
\end{tabular}

Note: All variables are binary with affirmative responses equal to one.

Source: World of Work research cluster, University of Sydney. 
Table 2. Pairwise correlations for dependent and independent variables.

\begin{tabular}{|c|c|c|c|c|c|c|c|c|c|c|c|c|c|c|c|c|}
\hline Variable & 1 & 2 & 3 & 4 & $\mathbf{5}$ & 6 & 7 & 8 & 9 & 10 & 11 & 12 & 13 & 14 & 15 & 16 \\
\hline 1. PAID MATERNITY LEAVE & - & & & & & & & & & & & & & & & \\
\hline 2. UNPAID PARENTAL LEAVE & -.08 & - & & & & & & & & & & & & & & \\
\hline 3. CHILD UNDER 10 & .02 & .07 & - & & & & & & & & & & & & & \\
\hline 4. FEMALE & -.04 & .20 & -.04 & - & & & & & & & & & & & & \\
\hline 5. PUBLIC SECTOR & .29 & .11 & -.04 & .07 & - & & & & & & & & & & & \\
\hline 6. UNIONIZED & .22 & .04 & .01 & -.07 & .24 & - & & & & & & & & & & \\
\hline 7. MEDIUM-SIZED WORKPLACE & .10 & -.04 & .03 & .04 & .05 & -.03 & - & & & & & & & & & \\
\hline 8. LARGE WORKPLACE & .13 & .02 & -.01 & -.03 & .09 & .19 & -.53 & - & & & & & & & & \\
\hline 9. ORGANIZATIONAL SUBUNIT & .15 & .02 & .06 & .03 & .13 & .07 & .13 & .00 & - & & & & & & & \\
\hline 10. MIDDLE INCOME & .18 & -.02 & .08 & -.20 & .15 & .19 & .06 & .14 & .06 & - & & & & & & \\
\hline 11. HIGH INCOME & -.06 & .01 & .06 & -.13 & -.01 & .01 & -.02 & .12 & -.02 & -.17 & - & & & & & \\
\hline 12. FEMALE $x$ MIDDLE INCOME & .10 & .18 & -.04 & .33 & .16 & .09 & .01 & .11 & .05 & .46 & -.08 & - & & & & \\
\hline 13. FEMALE $x$ HIGH INCOME & -.02 & .12 & .00 & .13 & .04 & -.02 & -.02 & .04 & .01 & -.07 & .43 & -.03 & - & & & \\
\hline 14. LIFE STAGE & .09 & .09 & .35 & -.03 & -.01 & -.04 & .02 & -.01 & .03 & .10 & -.02 & .07 & .05 & - & & \\
\hline 15. FEMALE $x$ LIFE STAGE & -.01 & .20 & .18 & .58 & .06 & -.10 & .05 & -.02 & .02 & -.05 & -.05 & .30 & .14 & .52 & - & \\
\hline 16. MANAGER & .17 & -.01 & .07 & .02 & .23 & .06 & .05 & .10 & .01 & .23 & .15 & .24 & .10 & .03 & .04 & - \\
\hline 17. FEMALE $x$ MANAGER & .10 & .16 & .02 & .43 & .23 & .11 & .02 & .09 & .01 & .10 & .00 & .46 & .18 & .02 & .29 & .61 \\
\hline
\end{tabular}

Note: All variables are binary with affirmative responses equal to one.

Source: World of Work research cluster, University of Sydney. 
Table 3. Taxonomy of nested logistic regression models that display the fitted relationship (including asymptotic standard errors) between whether one works in a workplace that offers paid maternity leave benefits and characteristics of the employee, the

\begin{tabular}{|c|c|c|c|c|c|c|c|c|c|c|c|c|}
\hline \multirow[b]{2}{*}{ Variable } & \multicolumn{12}{|c|}{ Model } \\
\hline & Null & M1 & M2 & M3 & M4 & M5 & M6 & M7 & M8 & M9 & M10 & M11 \\
\hline Intercept & $\begin{array}{l}0.40 * * * * \\
(0.0736)\end{array}$ & $\begin{array}{l}0.51 * * * * \\
(0.1211)\end{array}$ & $\begin{array}{r}0.02 \\
(0.1348)\end{array}$ & $\begin{array}{r}-0.18 \\
(0.1452)\end{array}$ & $\begin{array}{r}-0.83^{* * * * *} \\
(0.1997)\end{array}$ & $\begin{array}{r}-1.17 * * * * \\
(0.229)\end{array}$ & $\begin{array}{r}-1.15 * * * * \\
(0.2372)\end{array}$ & $\begin{array}{r}-1.09 * * * \\
(0.2631)\end{array}$ & $\begin{array}{r}-1.23 * * * * \\
(0.2738)\end{array}$ & $\begin{array}{r}-1.35 * * * * \\
(0.2864)\end{array}$ & $\begin{array}{r}-1.39^{* * * * *} \\
(0.2872)\end{array}$ & $\begin{array}{r}-1.39 * * * * \\
(0.2901)\end{array}$ \\
\hline FEMALE & & $\begin{array}{r}-0.18 \\
(0.1527)\end{array}$ & $\begin{array}{r}-0.35 * \\
(0.1641)\end{array}$ & $\begin{array}{c}-0.29^{\sim} \\
(0.1664)\end{array}$ & $\begin{array}{c}-0.28^{\sim} \\
(0.1699)\end{array}$ & $\begin{array}{r}-0.26 \\
(0.1715)\end{array}$ & $\begin{array}{r}-0.29 \\
(0.1814)\end{array}$ & $\begin{array}{r}-0.36 \\
(0.2403)\end{array}$ & $\begin{array}{r}-0.36 \\
(0.2411)\end{array}$ & $\begin{array}{r}-0.16 \\
(0.2754)\end{array}$ & $\begin{array}{r}-0.18 \\
(0.2764)\end{array}$ & $\begin{array}{r}-0.18 \\
(0.2877)\end{array}$ \\
\hline PUBLIC SECTOR & & & $\begin{array}{l}1.60 * * * * \\
(0.1703)\end{array}$ & $\begin{array}{l}1.44 * * * \\
(0.1755)\end{array}$ & $\begin{array}{l}1.38 \text { **** } \\
(0.1788)\end{array}$ & $\begin{array}{l}1.34 * * * * \\
(0.1797)\end{array}$ & $\begin{array}{l}1.33 * * * * \\
(0.1822)\end{array}$ & $\begin{array}{l}1.33 * * * * \\
(0.1825)\end{array}$ & $\begin{array}{l}1.33 * * * * \\
(0.1832)\end{array}$ & $\begin{array}{l}1.33 * * * * \\
(0.1831)\end{array}$ & $\begin{array}{l}1.24 * * * * \\
(0.1869)\end{array}$ & $\begin{array}{l}1.24 * * * * \\
(0.1869)\end{array}$ \\
\hline UNIONIZED & & & & $\begin{array}{r}0.66^{* * * *} \\
(0.178)\end{array}$ & $\begin{array}{r}0.49^{* * *} \\
(0.1899)\end{array}$ & $\begin{array}{r}0.45 * \\
(0.1855)\end{array}$ & $\begin{array}{r}0.41 * \\
(0.188)\end{array}$ & $\begin{array}{r}0.41 * \\
(0.181)\end{array}$ & $\begin{array}{r}0.46^{*} \\
(0.1904)\end{array}$ & $\begin{array}{r}0.45^{*} \\
(0.1906)\end{array}$ & $\begin{array}{r}0.44 * \\
(0.1914)\end{array}$ & $\begin{array}{r}0.44^{*} \\
(0.192)\end{array}$ \\
\hline MEDIUM-SIZED WORKPLACE & & & & & $\begin{array}{l}0.90^{* * * *} \\
(0.2042)\end{array}$ & $\begin{array}{l}0.82^{* * * *} \\
(0.2083)\end{array}$ & $\begin{array}{l}0.81 * * * * \\
(0.2111)\end{array}$ & $\begin{array}{l}0.81 * * * * \\
(0.2113)\end{array}$ & $\begin{array}{l}0.80^{* * * * *} \\
(0.2121)\end{array}$ & $\begin{array}{l}0.81 * * * * \\
(0.2125)\end{array}$ & $\begin{array}{l}0.77 * * * \\
(0.2141)\end{array}$ & $\begin{array}{l}0.77 * * * \\
(0.2142)\end{array}$ \\
\hline LARGE WORKPLACE & & & & & $\begin{array}{r}1.07 * * * * \\
(0.226)\end{array}$ & $\begin{array}{r}1.09 * * * * \\
(0.229)\end{array}$ & $\begin{array}{l}1.12 * * * * \\
(0.2376)\end{array}$ & $\begin{array}{l}1.12 * * * * \\
(0.2378)\end{array}$ & $\begin{array}{l}1.11 * * * * \\
(0.2386)\end{array}$ & $\begin{array}{l}1.11 * * * * \\
(0.2392)\end{array}$ & $\begin{array}{l}1.06 * * * \\
(0.2405)\end{array}$ & $\begin{array}{l}1.06 * * * * \\
(0.2405)\end{array}$ \\
\hline ORGANIZATIONAL SUBUNIT & & & & & & $\begin{array}{l}0.59 * * * * \\
(0.1796)\end{array}$ & $\begin{array}{l}0.58 * * * \\
(0.1742)\end{array}$ & $\begin{array}{l}0.58 * * * * \\
(0.1742)\end{array}$ & $\begin{array}{l}0.58^{* * * * *} \\
(0.1747)\end{array}$ & $\begin{array}{l}0.57^{* * *} \\
(0.175)\end{array}$ & $\begin{array}{r}0.58^{* * *} \\
(0.1762)\end{array}$ & $\begin{array}{r}0.57 * * * \\
(0.1762)\end{array}$ \\
\hline MIDDLE INCOME & & & & & & & $\begin{array}{r}0.17 \\
(0.1977)\end{array}$ & $\begin{array}{r}0.06 \\
(0.2974)\end{array}$ & $\begin{array}{r}0.03 \\
(0.2987)\end{array}$ & $\begin{array}{r}0.01 \\
(0.3003)\end{array}$ & $\begin{array}{r}-0.04 \\
(0.3025)\end{array}$ & $\begin{array}{r}-0.04 \\
(0.3052)\end{array}$ \\
\hline HIGH INCOME & & & & & & & $\begin{array}{r}-0.50 \\
(0.3096)\end{array}$ & $\begin{array}{r}-0.52 \\
(0.3977)\end{array}$ & $\begin{array}{r}-0.50 \\
(0.4003)\end{array}$ & $\begin{array}{r}-0.48 \\
(0.404)\end{array}$ & $\begin{array}{r}-0.62 \\
(0.4095)\end{array}$ & $\begin{array}{r}-0.62 \\
(0.417)\end{array}$ \\
\hline FEMALE $x$ MIDDLE INCOME & & & & & & & & $\begin{array}{r}0.20 \\
(0.386)\end{array}$ & $\begin{array}{r}0.18 \\
(0.3873)\end{array}$ & $\begin{array}{r}0.22 \\
(0.3893)\end{array}$ & $\begin{array}{r}0.10 \\
(0.3938)\end{array}$ & $\begin{array}{r}0.11 \\
(0.4066)\end{array}$ \\
\hline FEMALE $x$ HIGH INCOME & & & & & & & & $\begin{array}{r}-0.02 \\
(0.6297)\end{array}$ & $\begin{array}{r}-0.11 \\
(0.6278)\end{array}$ & $\begin{array}{r}-0.08 \\
(0.6338)\end{array}$ & $\begin{array}{r}-0.14 \\
(0.6397)\end{array}$ & $\begin{array}{r}-0.13 \\
(0.6567)\end{array}$ \\
\hline LIFE STAGE & & & & & & & & & $\begin{array}{c}0.33^{\sim} \\
(0.1704)\end{array}$ & $\begin{array}{r}0.66 * \\
(0.2806)\end{array}$ & $\begin{array}{r}0.62 * \\
(0.2823)\end{array}$ & $\begin{array}{r}0.61 * \\
(0.2828)\end{array}$ \\
\hline FEMALE $x$ LIFE STAGE & & & & & & & & & & $\begin{array}{r}-0.53 \\
(0.3515)\end{array}$ & $\begin{array}{r}-0.48 \\
(0.3538)\end{array}$ & $\begin{array}{r}-0.48 \\
(0.3542)\end{array}$ \\
\hline MANAGER & & & & & & & & & & & $\begin{array}{r}0.46^{*} \\
(0.1907)\end{array}$ & $\begin{array}{r}0.47 \\
(0.3039)\end{array}$ \\
\hline FEMALE $x$ MANAGER & & & & & & & & & & & & $\begin{array}{r}-0.01 \\
(0.3861)\end{array}$ \\
\hline$-2 L L$ & 1031.5 & 1030.2 & 930.2 & 916.1 & 889.2 & 877.5 & 873.1 & 872.8 & 869.0 & 866.8 & 860.8 & 860.8 \\
\hline$\chi^{2}$ (for the additional regressors) & - & 1.35 & $99.99^{* * * *}$ & $14.11^{1 * * *}$ & $26.88^{* * * *}$ & $11.66^{* * * * *}$ & 4.45 & 0.31 & $3.75^{\sim}$ & 2.29 & $5.95^{*}$ & 0.001 \\
\hline$\%$ of cases predicted correctly & 60.0 & 59.9 & 66.3 & 68.5 & 70.6 & 71.8 & 71.0 & 71.2 & 70.2 & 69.8 & 70.9 & 70.9 \\
\hline
\end{tabular}


Table 4. Taxonomy of nested logistic regression models that display the fitted relationship (including asymptotic standard errors) between whether one took unpaid maternity or paternity leave from work for their youngest child and characteristics of the

\begin{tabular}{|c|c|c|c|c|c|c|c|c|c|c|c|c|}
\hline \multirow[b]{2}{*}{ Variable } & \multicolumn{12}{|c|}{ Model } \\
\hline & Null & M1 & M2 & M3 & M4 & M5 & M6 & M7 & M8 & M9 & M10 & M11 \\
\hline Intercept & $\begin{array}{r}-0.74 * * * * * \\
(0.1133)\end{array}$ & $\begin{array}{r}-1.29 * * * * \\
(0.2028)\end{array}$ & $\begin{array}{r}-1.41 * * * * \\
(0.2207)\end{array}$ & $\begin{array}{r}-1.50 * * * \\
(0.2407)\end{array}$ & $\begin{array}{r}-1.32 * * * * \\
(0.3008)\end{array}$ & $\begin{array}{r}-1.28 * * * \\
(0.3959)\end{array}$ & $\begin{array}{r}-1.68 * * * * \\
(0.3774)\end{array}$ & $\begin{array}{c}-1.10^{*} \\
(0.4393)\end{array}$ & $\begin{array}{r}-1.36 * * \\
(0.485)\end{array}$ & $\begin{array}{r}-1.19^{*} \\
(0.5212)\end{array}$ & $\begin{array}{c}-1.19^{*} \\
(0.5219)\end{array}$ & $\begin{array}{r}-1.13^{*} \\
(0.5317)\end{array}$ \\
\hline FEMALE & & $\begin{array}{l}0.88 * * * \\
(0.2468)\end{array}$ & $\begin{array}{l}0.86 * * * \\
(0.2477)\end{array}$ & $\begin{array}{r}0.90 * * * * \\
(0.253)\end{array}$ & $\begin{array}{l}0.90 * * * \\
(0.2535)\end{array}$ & $\begin{array}{l}0.90 * * * * \\
(0.2536)\end{array}$ & $\begin{array}{l}1.27 * * * * \\
(0.3003)\end{array}$ & $\begin{array}{r}0.63 \\
(0.4019)\end{array}$ & $\begin{array}{r}0.62 \\
(0.4023)\end{array}$ & $\begin{array}{r}0.32 \\
(0.5312)\end{array}$ & $\begin{array}{r}0.32 \\
(0.5308)\end{array}$ & $\begin{array}{r}0.22 \\
(0.5599)\end{array}$ \\
\hline PUBLIC SECTOR & & & $\begin{array}{r}0.34 \\
(0.2375)\end{array}$ & $\begin{array}{r}0.27 \\
(0.2495)\end{array}$ & $\begin{array}{r}0.28 \\
(0.2505)\end{array}$ & $\begin{array}{r}0.29 \\
(0.2509)\end{array}$ & $\begin{array}{r}0.15 \\
(0.2601)\end{array}$ & $\begin{array}{r}0.12 \\
(0.2643)\end{array}$ & $\begin{array}{r}0.13 \\
(0.2648)\end{array}$ & $\begin{array}{r}0.13 \\
(0.2651)\end{array}$ & $\begin{array}{r}0.10 \\
(0.2764)\end{array}$ & $\begin{array}{r}0.10 \\
(0.2769)\end{array}$ \\
\hline UNIONIZED & & & & $\begin{array}{r}0.24 \\
(0.2597)\end{array}$ & $\begin{array}{r}0.26 \\
(0.274)\end{array}$ & $\begin{array}{r}0.27 \\
(0.2742)\end{array}$ & $\begin{array}{r}0.28 \\
(0.2824)\end{array}$ & $\begin{array}{r}0.26 \\
(0.2851)\end{array}$ & $\begin{array}{r}0.35 \\
(0.2933)\end{array}$ & $\begin{array}{r}0.35 \\
(0.2935)\end{array}$ & $\begin{array}{r}0.35 \\
(0.294)\end{array}$ & $\begin{array}{r}0.32 \\
(0.2967)\end{array}$ \\
\hline MEDIUM-SIZED WORKPLACE & & & & & $\begin{array}{r}-0.31 \\
(0.2921)\end{array}$ & $\begin{array}{r}-0.30 \\
(0.2922)\end{array}$ & $\begin{array}{r}-0.39 \\
(0.2966)\end{array}$ & $\begin{array}{r}-0.38 \\
(0.2967)\end{array}$ & $\begin{array}{r}-0.4 .2 \\
(0.2992)\end{array}$ & $\begin{array}{r}-0.42 \\
(0.2997)\end{array}$ & $\begin{array}{r}-0.4 .2 \\
(0.3006)\end{array}$ & $\begin{array}{r}-0.41 \\
(0.3019)\end{array}$ \\
\hline LARGE WORKPLACE & & & & & $\begin{array}{r}-0.16 \\
(0.3308)\end{array}$ & $\begin{array}{r}-0.17 \\
(0.3316)\end{array}$ & $\begin{array}{r}-0.37 \\
(0.3472)\end{array}$ & $\begin{array}{r}-0.38 \\
(0.3509)\end{array}$ & $\begin{array}{r}-0.41 \\
(0.3528)\end{array}$ & $\begin{array}{r}-0.40 \\
(0.353)\end{array}$ & $\begin{array}{r}-0.41 \\
(0.3548)\end{array}$ & $\begin{array}{r}-0.40 \\
(0.355)\end{array}$ \\
\hline ORGANIZATIONAL SUBUNIT & & & & & & $\begin{array}{r}-0.06 \\
(0.2426)\end{array}$ & $\begin{array}{r}-0.05 \\
(0.2447)\end{array}$ & $\begin{array}{r}-0.10 \\
(0.248)\end{array}$ & $\begin{array}{r}-0.06 \\
(0.24 .98)\end{array}$ & $\begin{array}{r}-0.05 \\
(0.2507)\end{array}$ & $\begin{array}{r}-0.06 \\
(0.2509)\end{array}$ & $\begin{array}{r}-0.06 \\
(0.2509)\end{array}$ \\
\hline MIDDLE INCOME & & & & & & & $\begin{array}{r}0.70 * \\
(0.3064)\end{array}$ & $\begin{array}{r}0.02 \\
(0.464)\end{array}$ & $\begin{array}{r}0.04 \\
(0.4649)\end{array}$ & $\begin{array}{r}0.02 \\
(0.4651)\end{array}$ & $\begin{array}{r}0.01 \\
(0.4658)\end{array}$ & $\begin{array}{r}0.05 \\
(0.4706)\end{array}$ \\
\hline HIGH INCOME & & & & & & & $\begin{array}{c}0.84^{\sim} \\
(0.4675)\end{array}$ & $\begin{array}{r}-0.06 \\
(0.6309)\end{array}$ & $\begin{array}{r}0.044 \\
(0.63544)\end{array}$ & $\begin{array}{r}-0.02 \\
(0.6395)\end{array}$ & $\begin{array}{r}-0.05 \\
(0.6478)\end{array}$ & $\begin{array}{r}0.03 \\
(0.6589)\end{array}$ \\
\hline FEMALE $x$ MIDDLE INCOME & & & & & & & & $\begin{array}{r}1.01^{\sim} \\
(0.589)\end{array}$ & $\begin{array}{c}1.00^{\sim} \\
(0.5905)\end{array}$ & $\begin{array}{c}1.03^{\sim} \\
(0.5921)\end{array}$ & $\begin{array}{r}1.01^{\sim} \\
(0.5969)\end{array}$ & $\begin{array}{r}0.91 \\
(0.6191)\end{array}$ \\
\hline FEMALE $x$ HIGH INCOME & & & & & & & & $\begin{array}{r}1.90^{\sim} \\
(1.0428)\end{array}$ & $\begin{array}{r}1.82^{\sim} \\
(1.044 .1)\end{array}$ & $\begin{array}{r}1.90^{\sim} \\
(1.0494)\end{array}$ & $\begin{array}{c}1.90^{\sim} \\
(1.0493)\end{array}$ & $\begin{array}{r}1.77^{\sim} \\
(1.0707)\end{array}$ \\
\hline LIFE STAGE & & & & & & & & & $\begin{array}{r}0.35 \\
(0.2643)\end{array}$ & $\begin{array}{r}0.07 \\
(0.4213)\end{array}$ & $\begin{array}{r}0.07 \\
(0.4213)\end{array}$ & $\begin{array}{r}0.05 \\
(0.4227)\end{array}$ \\
\hline FEMALE $x$ LIFE STAGE & & & & & & & & & & $\begin{array}{r}0.45 \\
(0.5254)\end{array}$ & $\begin{array}{r}0.45 \\
(0.5254)\end{array}$ & $\begin{array}{r}0.47 \\
(0.5268)\end{array}$ \\
\hline MANAGER & & & & & & & & & & & $\begin{array}{r}0.08 \\
(0.2778)\end{array}$ & $\begin{array}{r}-0.12 \\
(0.4444)\end{array}$ \\
\hline FEMALE $x$ MANAGER & & & & & & & & & & & & $\begin{array}{r}0.33 \\
(0.553)\end{array}$ \\
\hline$-2 L L$ & 44.7 .2 & 433.7 & 432.6 & 430.7 & 429.6 & 429.6 & 423.1 & 418.1 & 4.16 .3 & 415.6 & 415.5 & 415.2 \\
\hline$\chi^{2}$ (for the additional regressors) & - & $13.47 * * * *$ & 2.09 & 0.88 & 1.12 & 0.06 & $6.47^{*}$ & $4.99^{\sim}$ & 1.77 & 0.72 & 0.09 & 0.35 \\
\hline$\%$ of cases predicted correctly & 67.7 & 67.6 & 67.6 & 67.6 & 68.5 & 68.7 & 70.4 & 70.7 & 71.3 & 71.3 & 71.3 & 71.3 \\
\hline
\end{tabular}


Table 5. Prototypical probabilities for access to paid maternity leave and use of unpaid parental leave.

\begin{tabular}{|c|c|c|c|}
\hline & & Men & Women \\
\hline \multirow{4}{*}{$\begin{array}{l}\text { Access to } \\
\text { Paid } \\
\text { Maternity } \\
\text { Leave }\end{array}$} & union member & 0.60 & 0.50 \\
\hline & public servant & 0.77 & 0.69 \\
\hline & both & 0.84 & 0.78 \\
\hline & neither & 0.49 & 0.39 \\
\hline \multirow{4}{*}{$\begin{array}{l}\text { Use of Unpaid } \\
\text { Parental } \\
\text { Leave }\end{array}$} & union member & 0.25 & 0.45 \\
\hline & public servant & 0.21 & 0.39 \\
\hline & both & 0.26 & 0.47 \\
\hline & neither & 0.19 & 0.37 \\
\hline
\end{tabular}

Note: Probabilities are calculated using the logit transformation on parameter estimates from M11 in Tables 3 and 4 and setting all control variables to their sample means.

Source: World of Work research cluster, University of Sydney. 